\title{
Screening Jatropha genotypes for aluminum tolerance using the solution-paper method
}

\author{
Seleção de genótipos de pinhão-manso tolerantes ao alumínio \\ usando o método papel-solução
}

\author{
Renato Domiciano Silva Rosado ${ }^{1 *}$; Gustavo Sessa Fialho²; \\ Bruna Anair Souto Dias; ; Tatiana Barbosa Rosado \\ Herminia Emilia Prieto Martinez ${ }^{5}$; Bruno Galvêas Laviola ${ }^{4}$
}

\begin{abstract}
The identification of genetic material tolerant to aluminum (Al) can offer important advantages to breeding programs and to recommendations for cultivars with the aim of utilizing acidic soil. Based on this, our aim was to determine, by using the solution-paper method, the aluminum concentration that best demonstrates tolerance of Jatropha accessions to this element. For this study, seeds from eight Jatropha accessions (CNPAE 114, CNPAE 154, CNPAE 169, CNPAE 178, CNPAE 218, CNPAE 200, CNPAE 226, CNPAE 228) were placed in a germination chamber with different concentrations of Al $\left(0,85,155,225\right.$ and $\left.295 \mathrm{mg} \mathrm{L}^{-1}\right)$ using the solution-paper technique. After 14 days, the length of the primary root was evaluated and the percentage by which those subjected to doses of Al was calculated. A concentration of $85 \mathrm{mg} \mathrm{L}^{-1}$ was the level that separated the accessions in terms of Al tolerance; the accessions CNPAE 114 and CNPAE 154 were the most sensitive to the presence of this toxic element in the solution. It was concluded that the solution-paper method is efficient and can be used in Jatropha breeding programs for the selection of Al-tolerant genotypes.
\end{abstract}

Key words: Jatropha curcas, mineral nutrition, toxicity, genetic variability, breeding

\section{Resumo}

A identificação de material genético tolerante ao alumínio (Al) pode oferecer importantes subsídios aos programas de melhoramento e à recomendação de cultivares destinada a utilização de solos ácidos. Assim, o objetivo deste trabalho foi determinar, através do método de papel-solução, a concentração de alumínio que melhor discrimine acessos de pinhão-manso quanto à tolerância ao Al. Para este estudo, sementes de oito acessos de pinhão-manso (CNPAE 114, CNPAE 154, CNPAE 169, CNPAE 178, CNPAE 218, CNPAE 200, CNPAE 226, CNPAE 228) foram colocadas para germinar em diferentes concentrações de $\mathrm{Al}\left(0,85,155,225\right.$ e $\left.295 \mathrm{mg} \mathrm{L}^{-1}\right)$ utilizando a técnica do papel solução. Após 14 dias o comprimento da raiz primária foi avaliado e a porcentagem de redução foi calculada para os

\footnotetext{
1 Pesquisador Dr. em Fitotecnia, Melhorista de Milho Tropical na Empresa Geneze Sementes S/A, Paracatu, MG. E-mail: rosado. rds@gmail.com

2 Prof. Dr. em Fitotecnia, Instituto Federal de Educação Ciência e Tecnologia de Roraima, Campus Novo Paraíso, IFRR. E-mail: gsfialho@hotmail.com

3 Prof $^{a}$ Dr $^{\mathrm{a}}$ em Ciência Florestal no Dept ${ }^{0}$ de Ciências Florestais da Universidade Federal de Lavras, UFLA, Lavras, MG. E-mail: brunapropri@yahoo.com.br

4. Pesquisadores Drs. Embrapa Agroenergia, Empresa Brasileira de Pesquisa Agropecuária, Embrapa Agroenergia, Parque Estação Biólogica PqEB, Brasilia, DF. E-mail: bruno.laviola@embrapa.br; tatianarosado@yahoo.com.br

5 Prof $^{a}$ Dr $^{\mathrm{a}}$ em Solos e Nutrição de Plantas Fitotecnia, Ciências Agrárias, Dept ${ }^{0}$ de Fitotecnia, UFLA, Viçosa, MG. E-mail: herminia@ufv.br

* Author for correspondence
} 
sujeitados as doses de Al. A concentração de $85 \mathrm{mg} \mathrm{L}^{-1}$ foi a que melhor separou os acessos, em termos de tolerância ao Al, e que os acessos CNPAE 114 e CNPAE 154 foram os mais sensíveis à presença do elemento tóxico na solução. Concluiu-se que o método do papel solução é eficiente e pode ser usado em programa de melhoramento de pinhão-manso visando a seleção de genótipos tolerantes ao alumínio.

Palavras-chave: Jatropha curcas, nutrição mineral, toxidade, variabilidade genética, melhoramento

\section{Introduction}

Jatropha curcas is a species of the Euphorbiaceae family that is cultivated in tropical countries. It has promising medicinal uses, in addition to its large potential for biodiesel yield by extracting oil from the seeds (SATURNINO et al., 2005). Jatropha has the potential to produce more than two tons of oil per hectare, taking three to four years to achieve a productive age which can then last for 40 years (ÉGUIA, 2006). This species is adaptable to a wide climatic range, with average temperatures of between 18 and $28.5^{\circ} \mathrm{C}$, an average rainfall of 480 to $2,380 \mathrm{~mm}$ and altitudes of 1,000 meters (BELTRÃO et al., 2006).

Considering the interest in fuel production resulting from renewable sources, ample opportunities have arisen to grow Jatropha in Brazil. However, levels of aluminum in most Brazilian soils frequently reach toxic levels for these plants (SILVA et al., 2007). Its toxicity is, in general, the limiting production factor in cultures with acidic soil. It interferes with plant development, reducing germination in some species and, when it is present in elevated concentrations, it affects the development of the root system, increasing the root diameter and reducing the number of absorbent roots, therefore making uptake of nutrient and water more difficult for the plants (MASCARENHAS et al., 2004).

The identification of tolerant genetic material could offer an important advantage to breeding programs and the recommendation of cultivatars whch are best able to take advantage of acidic soils (GRANADOS; PANDEY; CEBALLOS, 1993; LIMA; MIRANDA-FILHO; FURLANI, 1995). It is difficult to test for $\mathrm{Al}$ tolerance in field experiments due to the heterogeneity of the soil and the number of environmental variations, which do not allow damage caused by stress from this element to be isolated in an effective way, nor for damage to the roots to be evaluated; this causes significant mistakes in tidentifying tolerant genetic constitutions (SILVA et al., 2007).

The use of nutritive solutions containing $\mathrm{Al}$ in hydroponic cultivationallowsimmediateobservation of its inhibitory effects on root growth, avoiding the drawbacks of using soil, where selection intensity cannot be quantitatively controlled (BERTAN et al., 2006). A simple and quick method to evaluate the tolerance of plants to Al was proposed by Konzak, Polle and Kittrick (1976) and called the solution-paper method. Based on measurements of root length, the authors successfully evaluated the behavior of wheat, barley, rice, sorghum, maize and soya in response to aluminum. Another advantage of this method is ease of $\mathrm{pH}$ control by using a nutritive buffer solution.

Jatropha cultivation is currently widespread in diverse regions of Brazil, including cerrado regions, which requires selection of a genotype tolerant to presence of $\mathrm{Al}$ in the soil solution. For this reason, the aim of this work was to determine, using the solution-paper method, the concentration of aluminum that best distinguishes the tolerance of Jatropha accessions to this element.

\section{Material and Methods}

The experiment was conducted in the "Mineral Plant Nutrition" and "Seed Analyses and Technology" Laboratories of the Department of Phytotechnology, located at the geographic coordinates $20^{\circ} 45$ ' $31^{\prime}$ " latitude South and $42^{\circ}$ 52' 16" latitude West, of the Federal University of Viçosa (UFV), MG, Brazil, in September and October of 2008.

The treatments followed a completely randomized 
experimental design, with 40 treatments and four replicates containing five plantules. For each treatment, 25 Jatropha seeds were sowed between three sheets of germitest-type paper-towels $(28 \mathrm{~cm}$ $\mathrm{x} 38 \mathrm{~cm}$ ), previously moistened in the solution test. After seven days, five plantules were selected with protruding rootlets $(1 \mathrm{~cm})$ in order to constitute a replicate. These plantules were re-allocated in the solution-paper for a further seven days.

The treatments were distributed in a $5 \times 8$ factorial scheme, with five concentrations of $\mathrm{Al}(0$, $85,155,225,295 \mathrm{mg} \mathrm{L}^{-1}$ nutritive solution) obtained by dissolving $\mathrm{AlCl}_{3}$, and eight Jatropha accessions. Concentrations of $\mathrm{Al}$ selected were chosen based on information from preliminary experiments.

Genotypes from different regions of the country were chosen and supplied by the Brazilian Agricultural Research Corporation (Embrapa Agroenergy), being seeds from eight Jatropha accessions: CNPAE 228, CNPAE 114, CNPAE 154, CNPAE 169, CNPAE 178, CNPAE 200, CNPAE 218 and CNPAE 226, each originating, respectively, from the city, state, geographic coordinates of the matrices, and altitude: Barra do Bugre, MT, unknown origin; Umuarama, PR, S $23^{\circ} 47^{\prime} 55^{\prime \prime}, \mathrm{W}$ $53^{\circ} 18^{\prime}$ 48', 430 m; Janaúba, MG, S-1543’38,9”, W-4318'59,7', 534 m; Jaíba, MG, unknown origin; João Pinheiro, MG, S-1742'29,4”, W-46¹7'16”, 590 m; Lavras, MG, S-21¹3'28,6”, W-4458'27,4”, 912 m; São Miguel do Araguaia, GO, S-13 ${ }^{\circ} 55^{\prime} 57^{\prime}$ ', W-5009'17', $330 \mathrm{~m}$; Manduri, SP, lat. $23^{\circ} 10^{\prime} \mathrm{S}$, long. $49^{\circ} 20^{\prime} \mathrm{O}, 581 \mathrm{~m}$.

Using the solution-paper method (KONZAK; POLLE; KITTRICK, 1976), five plantules were carefully selected and conditioned in paper germitest rolls. These were arranged in a vertical position inside plastic pots of two liter capacity and containing a $250 \mathrm{~mL}$ sheet of nutritive solution, comprising different $\mathrm{Al}$ concentrations, in such a way as to maintain continual moisture at the base of the rolls.

The nutritive solution used to maintain the sheet in the bottom of the pots and to soak the germitest paper was composed of: $\mathrm{MgSO}_{4} 0.1 \mathrm{mmol} \mathrm{L}^{-1} \mathrm{KNO}_{3}$ $0.1 \mathrm{mmol} \mathrm{L}^{-1} \mathrm{NH}_{4} \mathrm{NO}_{3} 0.15 \mathrm{mmol} \mathrm{L}^{-1}$ and $\mathrm{KHC}_{8} \mathrm{H}_{4} \mathrm{O}_{8}$ $8.0 \mathrm{mmol} \mathrm{L}^{-1}$. The solution was replaced weekly in order to maintain the sheet in the bottom of the pots on a continuous basis.

The $\mathrm{pH}$ of the solution was constant and equal to 4.0 when using potassium biphthalate $\left(\mathrm{KC}_{8} \mathrm{H}_{5} \mathrm{O}_{4}\right)$ as a buffer. Due to the short time period involved in carrying out the assay, and considering the existence of reserves in the seeds, phosphorous was omitted to avoid precipitating the $\mathrm{Al}$.

The osmotic potential of the nutritive solutions was also maintained at a constant level in all treatments and at a level equal to the treatment with $295 \mathrm{mg} \mathrm{L}^{-1}$ of Al, using PEG 6000. Concentrations of PEG were determined by the equation: $\Psi$ os $=-$ $\left(1.18 \times 10^{-2}\right) \mathrm{C}-\left(1.18 \times 10^{-4}\right) \mathrm{C}^{2}+\left(2.67 \times 10^{-4}\right) \mathrm{CT}+$ $\left(8.39 \times 10^{-7}\right) \mathrm{C}^{2} \mathrm{~T}$ (MICHEL; KAUFMANN, 1973) and corresponded to the following: $82.4 \mathrm{~g} \mathrm{~L}^{-1}, 66.5 \mathrm{~g}$ $\mathrm{L}^{-1}, 50.9 \mathrm{~g} \mathrm{~L}^{-1}, 31.4 \mathrm{~g} \mathrm{~L}^{-1}$, and $0.0 \mathrm{~g} \mathrm{~L}^{-1}$, respectively, for the treatments of $0,85,155,225,295 \mathrm{mg} \mathrm{L}^{-1}$ of $\mathrm{Al}$ in a nutritive solution.

Fourteen days after sowing, the length of the primary root was measured for all treatments. The percentage rate of reduction was calculated from the length of the primary root in comparison to the length of plantule roots that did not receive $\mathrm{Al}$, following the formula: $\{\% \mathrm{RCR}=[1$-(growth with aluminum / growth without aluminum)] x 100\}.

The data were subjected to an analysis of variance (ANOVA), regression study and an average grouping analysis (Scott and Knott test) with a $5 \%$ probability level. When performing the statistical analyses, the computational application in the genetics and statistics program GENES was used (CRUZ, 2006).

\section{Results and Discussion}

Our results indicated that Jatropha plantules grow reasonably well in environments with considerably 
elevated rates of Al solutions (Figure 1). Macedo and Lopes (2008) note that, in two cultivars of Catuaí Amarelo IAC 86 and Apoatã coffee, a dose of 45 $\mathrm{mg} \mathrm{L}^{-1}$ of Al was able to distinguish between the two cultivars in terms of tolerance to this element. These results were similar to those found by Konzak, Polle and Kittrick (1976) for soybean and by Braccini, Martinez and Braccini (2000) for coffee.

Figure 1. Growth percentage of the primary root of Jatropha curcas plantules as a function of concentrations of $\mathrm{Al}$ in the solution-paper. B, C, D, E, F, G, H, represent the accessions, respectively: CNPAE-228, CNPAE-114, CNPAE-154, CNPAE-154, CNPAE-169, CNPAE-178, CNPAE-200, CNPAE-218, CNPAE-226
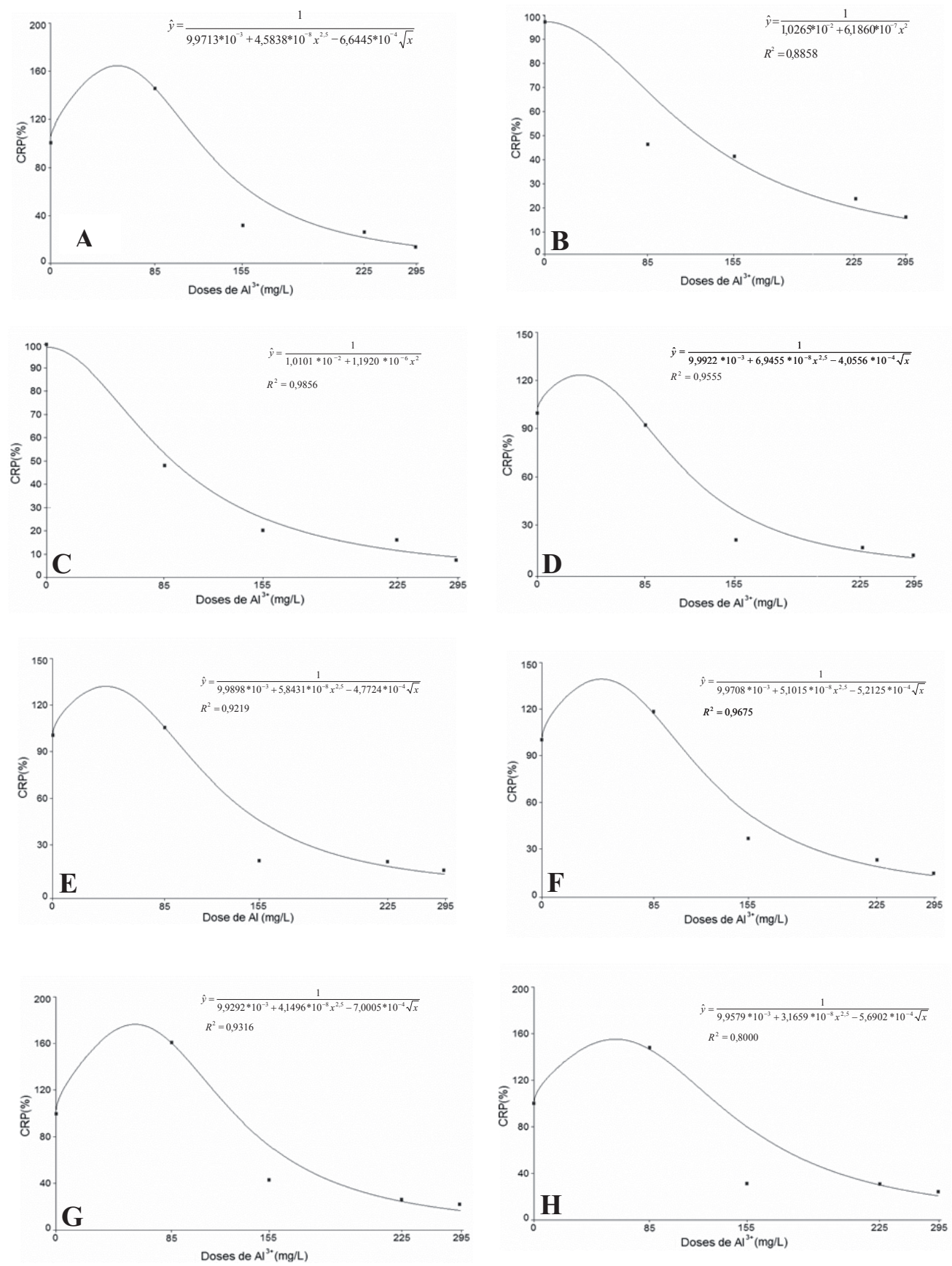

Source: Elaboration of the authors. 
In the most elevated concentrations of $\mathrm{Al}$ doses ( $>85 \mathrm{mg} \mathrm{L}^{-1}$ ), the length of the primary root and the development of the side roots of Jatropha plantules were influenced negatively, leading to thickening and yellowing of the tips (Figures 1 and 2). The easiest symptom of $\mathrm{Al}$ poisoning to observe is root growth inhibition, which indicates stress in this plant caused by Al. Symptoms of Al poisoning observed in Jatropha coincided with reports from other species, for example coffee (BRACCINI; MARTINEZ; BRACCINI, 2000; MACEDO; LOPES, 2008), soybean (SILVA; NOVAIS; SEDIYAMA, 1984) and rice (FREIRE et al., 1987).

Figure 2. Behavior of the eight Jatropha curtas plantule accessions in solution-paper in response to Al concentrations of $\left(0 ; 85 ; 155 ; 225\right.$ and $\left.295 \mathrm{mg} \mathrm{L}^{-1}\right)$ from left to right in the photographs, respectively.
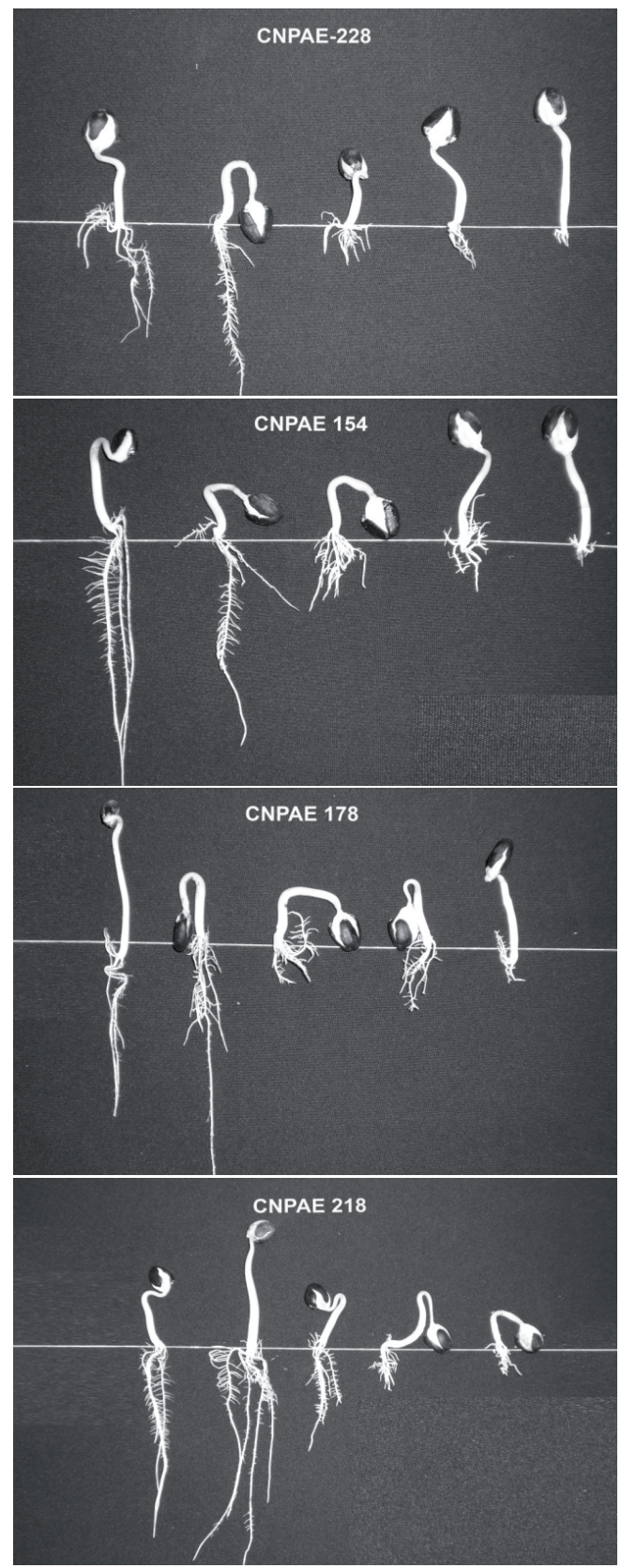

Source: Elaboration of the authors.
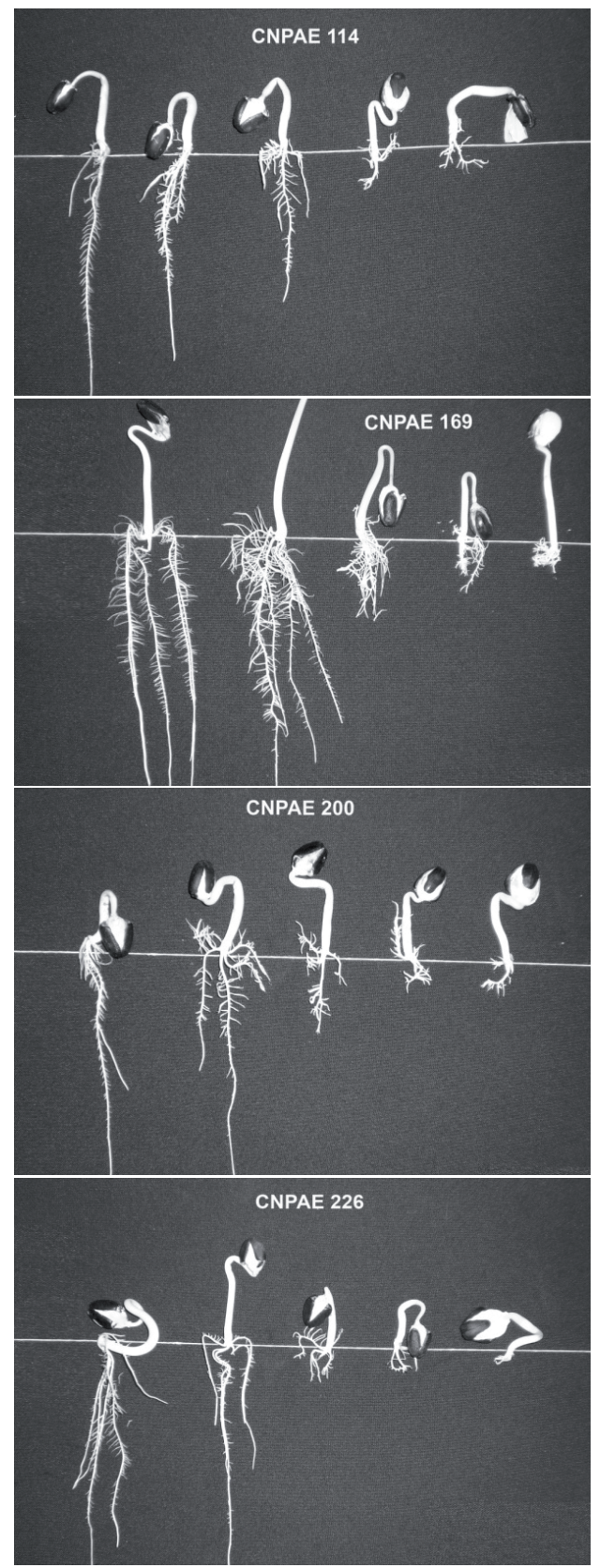
When analyzing the length of the primary root in the different accessions, it can be seen that a concentration of $85 \mathrm{mg} \mathrm{L}^{-1}$ of $\mathrm{Al}$ in solutionpaper can be used to distinguish the accessions in terms of tolerance to Al (Figures 1 and 2), when the remaining concentration of the material had a similar behavior. Furthermore, in very elevated or very low concentrations, the differences between the accessions tended to be eliminated. One of the main problems for plant selection in terms of tolerance to Al was found to be adjusting the concentration of Al-stress in such a way as to produce accentuated reductions in growth of the sensitive genotypes, while limiting the effects on growth of the tolerant genotypes (MACEDO; KINET; SINT JAN, 1997). For species such as soybean, Konzak, Polle and Kittrick (1976) verified that the Al concentration required to produce toxic effects in plantules using the solution-paper technique was approximately ten times higher than that used in the nutritive solution.

A small increase in the growth of the primary root was noted in five Jatropha accessions (CNPAE-228, CNPAE-178, CNPAE-200, CNPAE-218, CNPAE-226), when Al was added in concentrations of $85 \mathrm{mg} \mathrm{L}^{-1}$ (Figures 1 and 2). According to Sivaguru and Horst (1998), the primary site of toxic action from $\mathrm{Al}$ is the distal part of the transition zone at the top of the roots where the cells enter a lengthening phase. The growth inhibition of the root is the fastest visible symptom of $\mathrm{Al}$ poisoning in plants. Although Al can be poisonous and cause the inhibition of vital functions of linked elements, such as enzymes, calmodulin, ATP, GTP, DNA, or other metabolic processes (DELHAIZE; RYAN, 1995), we did not verify such effects on these accessions in our study.

Possibly due to the element having only penetrated the apoplast, without reaching the symplast where it might compromise cellular function (MACEDO; LOPES, 2008), these results corroborate the affirmations of Szymanska and Molas(1996), according to which low concentrations of Al can stimulate initial development of the vegetable, without toxic effects. As such, $\mathrm{Al}$ at this concentration should not be toxic to these Jatropha accessions, stimulating the initial development of the plant without causing toxic effects while directly affecting root lengthening.

Authors such as Nuernberg et al. (1990) point out that the absolute root length must not be used for selection procedures, since it does not clearly separate tolerant from sensitive cultivars, and different cultivars can have different growth rates. As such, root length values were expressed in terms of reduction or increase percentages caused by Al. In this form, Jatropha accessions were grouped into functions of tolerance to $\mathrm{Al}$ in a solution of $85 \mathrm{mg} \mathrm{L}^{-1}$, based on the percentage of increase or reduction in growth of the primary root of the plants (CRP\%). The best performance was observed for the CNPAE 218 accession $(\mathrm{CRP} \%=160 \mathrm{a})$ differing from the others, based on the Scott and Knott test at $5 \%$ probability. The second group comprised the accessions CNPAE $226(\mathrm{CRP} \%=140 \mathrm{~b})$ and CNPAE $228(\mathrm{CRP} \%=137 \mathrm{~b})$ which did not differ $(\mathrm{p}>0.05)$. The third group was formed of the accession CNPAE $200(\mathrm{CRP} \%=120 \mathrm{c})$. The fourth group consisted of the CNPAE 178 accession $(C R P \%=101 d)$. These accessions, in an $85 \mathrm{mg} \mathrm{L}^{-1}$ of $\mathrm{Al}$, did not present any reductions in root growth. The same was not found for other accessions (CNPAE 169 - CRP\% $=88 \mathrm{e}, \mathrm{CNPAE} 154-\mathrm{CRP} \%=43 \mathrm{f}$, CNPAE $114-$ $\mathrm{CRP} \%=42 \mathrm{f})$.

The accessions presented different responses to the concentrations of $\mathrm{Al}$ in solution, which indicated the existence of genetic control in tolerance to Al in Jatropha (Figure 1). According to Purcino et al. (2001), tolerance mechanisms to Al can be morphological, physiological, biochemical, or any combination of these. Regarding the internal tolerance of the root, the following is notable: the action of polypeptides in the cytoplasm as chelating molecules; the existence of enzymes whose activity is not damaged by $\mathrm{Al}$; and the elimination of $\mathrm{Al}$ from the cellular environment by compartmentalization in the vacuole (ABICHEQUER; BOHNEN; 
ANGHINONI, 2003). It should also be taken into account that the compounds are easily solubilized in acidic conditions, influencing the metabolism from minerals; the energy of the plants should also be considered (LARCHER, 2000). The accessions CNPAE-114, CNPAE-154 and CNPAE-169 are notable as sensitive materials at a concentration of $85 \mathrm{mg} \mathrm{L}^{-1}$, with average reductions in the length of the root system of 53.85, 51.93 and $7.62 \%$ respectively.

\section{Conclusions}

The Jatropha accessions have differentiated behavior with respect to tolerance to aluminum.

The solution-paper method allows the selection of Jatropha genotypes in terms of Al tolerance.

A concentration of $85 \mathrm{mg} \mathrm{L}^{-1}$ of $\mathrm{Al}$ using the solution-paper technique was the best of those studied for detection of differences between Jatropha accessions in terms of tolerance to Al.

\section{Acknowledgments}

We thank Embrapa Agroenergy for providing biological material, and CNPq (Conselho Nacional de Desenvolvimento Científico e Tecnológico, Brazil) for providing financial support.

\section{References}

ABICHEQUER, A. D.; BOHNEN, H.; ANGHINONI, I. Absorção, translocação e utilização de fósforo por variedades de trigo submetidas à toxidez de alumínio. Revista Brasileira de Ciência do Solo, Campinas, v. 27, p. 373-378, 2003.

BELTRÃO, N. E. de M.; SEVERINO, L. S.; VELOSO, J. F.; JUNQUEIRA, N.; FIDELIS, M.; GONÇALVES, N. P.; SATURNINO, H. M.; ROSCOE, R.; GAZZONI, D.; DUARTE, J. O.; DRUMOND, M. A.; ANJOS, J. B. Alerta sobre o plantio de pinhão manso no Brasil. Campina Grande: Embrapa Algodão, 2006. 15 p. (Embrapa Algodão. Documentos, 155).
BERTAN, I.; CARVALHO, F. I. F.; OLIVEIRA, A. C.; SILVA, J. A. G.; BENIN, G.; VIEIRA, E. A.; SILVA, G. O.; HARTWING, I.; VALERIO, I. P.; FINATTO, T. Dissimilaridade genética entre genótipos de trigo avaliados em cultivo hidropônico sob estresse por alumínio. Bragantia, Campinas, v. 65 , n. 1, p. 55-63, 2006.

BRACCINI, M. C. L.; MARTINEZ, H. E. P.; BRACCINI, A. L. Avaliação de linhagens de cafeeiros quanto à tolerância ao alumínio pelo método do papel-solução. Bragantia, Campinas, v. 59, n. 2, p. 221-226, 2000.

CRUZ, C. D. Programa genes-biometria. Viçosa: UFV, 2006. v. 1, 382 p.

DELHAIZE, E.; RYAN, P. R. Aluminum toxicity and tolerance in plants. Plant Physiology, Minneapolis, v. 107, n. 2, p. 315-321, 1995.

ÉGUIA, M. T. J. Pinhão manso e biodiesel. In: SALEME, W. J. L. Potencial de pinhão-manso para o programa nacional do biodisel. Brasília, DF: FEPAD: UNB, 2006. Disponível em: <www.fepad.org.br>. Acesso em: 7 set. 2008.

FREIRE, L. R.; AMARAL SOBRINHO, N. M. B.; FERNANDES, M. S.; RIBEIRO, M. E. S.; SANTOS, J. C. P. Efeito de alumínio nas raízes de arroz cultivado em solução nutritiva. Pesquisa Agropecuária Brasileira, Brasília, v. 22, n. 5, p. 459-464, 1987.

GRANADOS, G.; PANDEY, S.; CEBALlOS, H. Response to selection for tolerance to acid soils in a tropical maize population. Crop Science, Madison, v. 33, n. 3, p. 936-940, 1993.

KONZAK, C. F.; POLLE, E.; KITTRICK, J. A. Screening several crops for aluminum tolerance. In: WORKSHOP ON PLANT ADAPTATION TO MINERAL STRESS IN PROBLEM SOILS, 1976, Beltsville. Proceedings... Ithaca: Cornell University Press, 1976. p. 311-327.

LARCHER, W. Ecofisiologia vegetal. São Paulo: Rima Artes e Textos, 2000. $531 \mathrm{p}$.

LIMA, M.; MIRANDA-FILHO, J. B.; FURLANI, P. R. Diallel cross among inbred lines of maize differing in aluminum tolerance. Revista Brasileira de Genética, Ribeirão Preto, v. 18, n. 4, p. 579-584, 1995.

MACEDO, C. C.; KINET, J. M.; SINT JAN, van V. Effects of duration and intensity of aluminum stress on growth parameters in four genotypes differing in aluminum sensitivity. Journal of Plant Nutrition, New York, v. 20, n. 1, p. 181-193, 1997. 
MACEDO, C. M. P.; LOPES, J. C. Qualidade fisiológica de semente de café arábica na presença de alumínio. Revista Brasileira de Sementes, Brasília, v. 30b, n. 1, p. 66-73, 2008.

MASCARENHAS, H. A. A.; TANAKA, R. T.; WUTKE, E. B.; BRAGA, N. R.; MIRANDA, M. Alumínio e manganês no cultivo da soja em São Paulo. OAgronômico, Campinas, v. 56, n. 1, p. 16-19, 2004.

MICHEL, B. E; KAUFMANN, M. R. The osmotic potential of polyethilene glycol 6000. Plant Physiology, Lancaster, v. 51, n. 6, p. 914-916, 1973.

NUERNBERG, N. J.; BISSANI, C. A.; CAMPBELL, T. A.; FOY, C. D. Screening pasture plants for aluminum tolerance. In: EL BASSAN, N.; DAMBROTH, M.; LOUGHMAN, B. C. (Ed.). Genetic aspects of plant mineral nutrition. Netherlands: Kluwer Academic Publishers, 1990. p. 345-353.

PURCINO, A. A. C.; ALVES, A. M. C.; GUIMARAES, C. T.; SOUZA, I. R. P.; CARNEIRO, N. P.; PAIVA, E.; PARENTONI, S. N. Aspectos fisiológicos, bioquímicos e moleculares da toxidez de alumínio em milho. In: ENCONTRO LATINO-AMERICANO DE BIOTECNOLOGIA VEGETAL, 4., 2001, Goiânia. Anais... Goiânia: [s.n.], 2001.

SATURNINO, H. M.; PACHECO, D. D.; KAKIDA, J.; TOMINAGA, N.; GONÇALVES, N.P. Cultura do pinhãomanso (Jatropha curcas L.). Informe Agropecuário, Belo Horizonte, v. 26, n. 229, p. 44-78, 2005.

SILVA, J. A. G.; CARVALHO, F. I. F.; COIMBRA, J. L. M.; VIEIRA, E. A.; BENIN, G.; OLIVEIRA, A. C.; FINATTO, T.; BERTAN, I.; SILVA, G. O.; CORREA, M. R. Tolerância ao alumínio em cultivares de aveia branca sob cultivo hidropônico. Bragantia, Campinas, v. 66, n. 4, p. 587-593, 2007.

SILVA, J. B. C.; NOVAIS, R. F.; SEDIYAMA, C. S. Comportamento de genótipos de soja em solo com alta saturação de alumínio. Pesquisa Agropecuária Brasileira, Brasília, v. 19, n. 3, p. 287-298, 1984.

SZYMANSKA, M.; MOLAS, J. The effect of aluminum on early development stages of Cucumis sativus L. Folia Horticulturae, Poznañ, v. 8, n. 1, p. 73-83, 1996. 